\title{
接合部パネルのせん断変形，鉄筋の付着すべりを考慮した 分割要素法による鉄筋コンクリート骨組の弾塑性解析法
}

\section{§1. 序 論}

最近では，住宅都市整備公団のアパートの実大実 験1), 2), 日米共同研究による鉄筋コンクリート(以下 $\mathrm{RC}$ と呼ぶ）造 7 階建 ${ }^{3)-6)}$, 鉄骨造 6 階建 ${ }^{7), 81}$ の実大実験 が行われているが，ほとんごの建築構造物は構造力学理 論の上に導かれた構造解析，構造計算によってその安全 性を確認しながら設計され建てられている。 RC 構造物 でも 30 階を越えるものが，純ラーメン構造で建てられ るようになってきたが，このような構造物の架構全体を 取り出し，実大実験によってその安全性を確認すること は不可能に近い。これに対し，近年のコンピュータの大 型化, 高速化は目覚しく, 構造物全体としての力学的挙 動を解析的に把握することは, 不可能ではないと考える。

鉄筋の付着特性を考慮した鉄筋コンクリートの解析的 研究は，すでに 2 次元および 3 次元有限要素法により， 数多くなされている ${ }^{9) \sim 11}$ が，それらの多くは柱，はり等 の部材を取り出し，個々の事象を理論的に詳細に説明す ることに主眼を置いている。野口ら ${ }^{12}$ は，有限要素法に より柱・はり接合部の挙動を詳細に解析している。これ は実験結果を精度よく追跡するのみでなく，接合部マク ロモデルの策定あるいは，検証を意図しているものであ る。しかし，有限要素法を用いて骨組まで解析している ものはほとんど見当らない。この主な原因は，有限要素 法を用いて骨組まで解析しようとすると，膨大な計算時 間を要することにある。 RC 骨組の解析を柱・はり接合 部の挙動，付着特性などを考虑して行うためには，有限 要素法等より簡便な方法を用いる必要があると考える。

断面を層状に分割する断面解析手法 ${ }^{13)}$, 14) 部材に拡張 した分割要素法 ${ }^{15)}$ と呼ばれる線材解析法がよく使われて いる。この方法は，有限要素法に比較し計算時間が短縮 できる，材料特性の取り込みが容易である等が特長であ

* 東京工業大学 助手

** 東京工業大学 助教授.工博

*** 東京工業大学 名誉教授. 工博 (昭和 62 年 10 月 9 日原稿受理)

$\begin{array}{lllll}\text { 正会員 } & \text { 坂 } & \text { 田 } & \text { 弘 } & \text { 安* } \\ \text { 正会員 } & \text { 和 } & \text { 田 } & & \text { 章** } \\ \text { 正会員 } & \text { 林 } & & \text { 静 } & \text { 雄** } \\ \text { 正会員 } & \text { 黒 } & \text { 正 } & \text { 清 } & \text { 治*** }\end{array}$

る。これに柱・はり接合部のモデルを付加することによ り，RC の骨組解析に適用しやすいものと考える。

分割要素法は， $\mathrm{RC}$ 部材の解析法として多くの研究者 により用いられており，主筋の付着すべりや，部材端で の主筋の抜け出し効果を考慮し得る解析モデルも提案さ

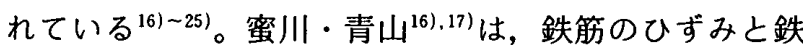
筋位置のコンクリートのひずみの間に付着の影響を考虑 して関係づけることにより，断面曲げ解析の手法がその まま分割要素法に適用できる方法を示した。谷・野村・ 永坂・平松 ${ }^{18)}$ は，等価定着長さに相当する分だけ部材を 長くみなし，見掛け上の部材剛性を低下させることによ り，主筋の抜け出し効果を考虑した。松浦・山本 ${ }^{19}$ は， コンクリートは平面保持のまま，鉄筋之の間にボンドリ ンクを介在させることにより付着のない試験体も解析で きることを示した。小阪・谷川・山田 ${ }^{20), 211}$ は，分割要素 法にエンドクロニック理論を適用して，その有効性を示 した。市之瀬 221.23 は，付着すべりを考慮した鉄筋連続法 を示した。上田・土橋 ${ }^{24), 25)} は$ ，主筋の付着すべりを考虑 した分割要素法により $\mathrm{RC}$ はりの，線形ならびに非線 形領域における曲げについて論じた。柱・はり接合部内 の鉄筋の付着すべりを考慮した解析も行われてい $る^{26) ~ 28)}$ 。O $\operatorname{tani}^{26)}$ は，接合部からの鉄筋の抜け出しによ る部材端部の回転を考慮して, RC 骨組の動的解析を 行った。多田・武田 ${ }^{27)}$ は，材端に仮想のヒンジ域を仮定 しここれに隣接する定着域を剛なコンクリートとして, ここにおける付着特性をボンドリンクで取り入れ，付着 劣化過程を定量的に評価し得る解析法を示した。Filippou, Popov, Bertero ${ }^{28)}$ は，柱・はり接合部内の鉄筋に ついてカのつり合い条件式をたて，材料モデルを厳密に モデル化することにより，繰り返し荷重を受けるはり材 端の挙動を解析的に説明した。また，柱・はり接合部の せん断変形を考虑した骨組解析法も数多く提案されてい $3^{29) .30)}$ 。以上，部材内の付着すべりを考歷した解析法お よび，せん断変形する柱・はり接合部を取り込んだ解析 法を列記したが，せん断変形する柱・はり接合部内の鉄 
筋の付着すべりまで含めて部材内の鉄筋と連続的に取り 扱い骨組にまで抎張しているものは，ほとんど見当たら ない。

筆者らはこれまで分割要素法を用いて，コンクリート の平面保持を仮定し，鉄筋の変位にすべりの自由度を加 えることにより，付着すべりを考慮した $\mathrm{RC}$ 部材の解

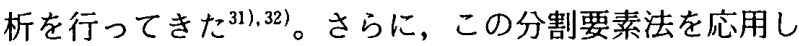
て, 柱・はり接合部のせん断変形とその内部の鉄筋の付 着すべり・降伏を考慮し得る解析法を誘導し，これを鉄

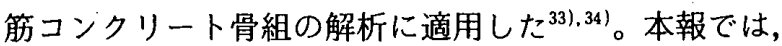

柱・はり接合部のせん断変形と鉄筋の付着すべりを考慮 し得る解析法を展開し，繰り返し荷重を受ける十字型 $\mathrm{RC}$ 骨組について解析例を示す。なお，本報は拙論 333 ),34) をもとに，加筆したものである。

\section{§2. 解析方法}

2.1 鉄筋コンクリート骨組のモデル化と解析上の仮定 モデルの概略を図一1 に示す。以下，部材を材軸方向 に分割しものを部材要素と称し，断面を層状に分割した ものを単位分割要素と称する。

1）鉄筋コンクリート部材

（a ）部材は,材軸方向に数十の部材要素に分割する。 部材要素ごとに独立な関係を用い，各部材要素の間で変 位と回転は連続性を保つが,それ以上の微分項(ひずみ・ 曲率等) の不連続は許容する。

(b) 各部材要素の変形は, 軸方向変形, 曲げ変形を 考慮し; せん断変形は無いものとする。

（c）各部材要素の断面分割は，コンクリート断面を せい方向に単位分割要素に層状分割し，鉄筋は別に扱う (図一2)。この際，フープ，スターラップ等によって拘 束された部分のコンクリート（コアコンクリート）とそ うでない部分のコンクリート（かぶりコンクリート）を 分けて考える。

（d） 断面内のひずみ，応力に関しては，断面の単位 分割要素中で一定とし，各単位分割要素の中心で代表さ せる。

（e）コンクリート断面に関する平面保持が成立する ものとする。ただし，鉄筋とコンクリートの間には付着 すべりを考慮しているので鉄筋のひずみは，同じ位置に あるコンクリートのひずみとは必ずしも一致しない。

（f） 部材要素内の応力, ひずみ状態は各部材要素の 両端の断面についてのみ追跡し, 部材要素内部の応力, ひすみ状態の追跡は行わない。ただし，ひずみエネルギ を計算する際には，内部の応力状態が必要であるが，こ れは両端における応力を用いて線形補間する ${ }^{35) 。 ~}$

2) 柱・はり接合部

柱・はり接合部は，接合部パネルとして扱う。接合部 パネルは，せん断変形を考える。せん断変形は接合部パ ネル内で一様であるとする。接合部パネル内部の鉄筋の

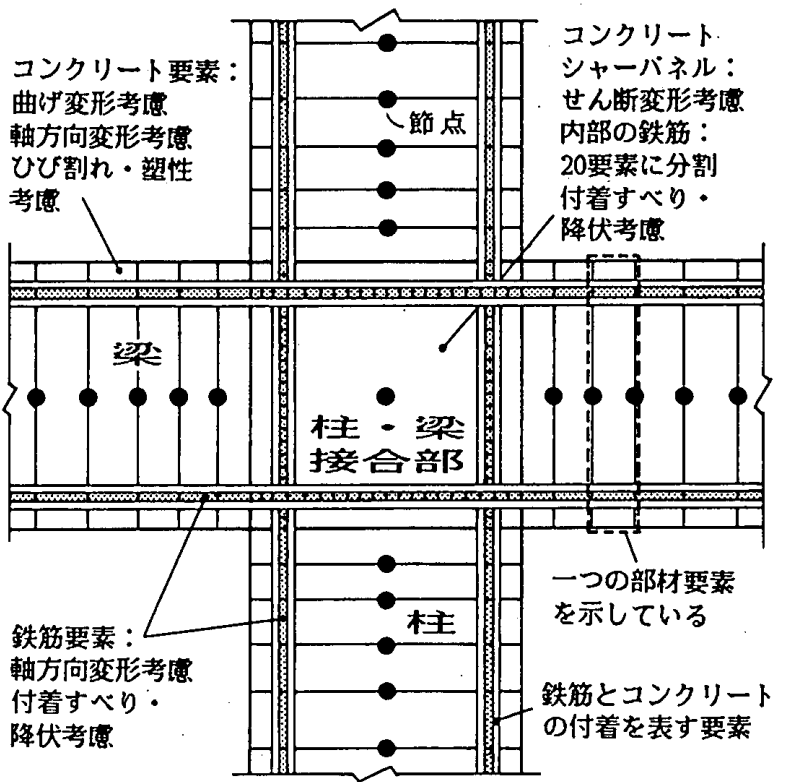

図一1＼cjkstart本解析法で用いる鉄筋コンクリート骨組モデル
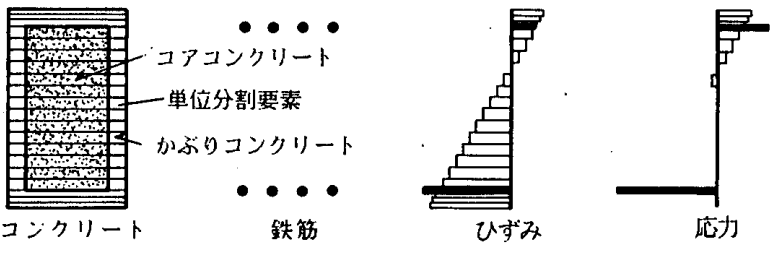

図一2 部材要素断面の分割とひずみ・応力

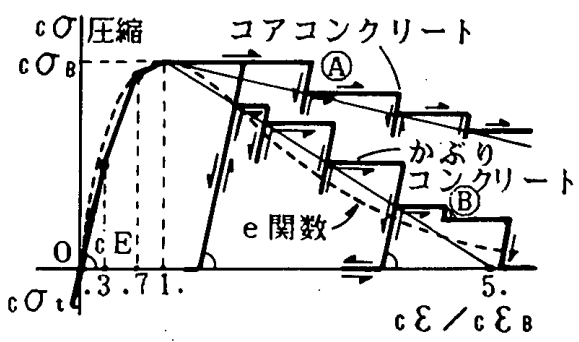

図一3 コンクリートの応力ーひずみ関係 ${ }^{36)}$

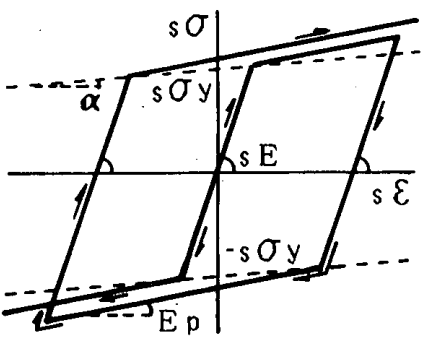

図一4 鉄筋の忘力ーひずみ関係 ${ }^{35}$

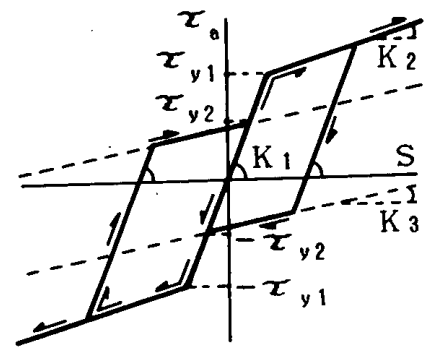

図一5 付着応力-すべり関係 ${ }^{33)}$ 
付着すべり・降伏を考慮するため，接合部パネル内にお いて，鉄筋の材軸方向に各鉄筋を 20 要素に分割する。

3）材料特性

（a）コンクリートの応力ーひずみ関係, 鉄筋の応力ひず関係，および主筋とコンクリートの付着すべりを 表すための付着応力ーすべり関係，およびコンクリート パネルの応力ーひずみ関係としてそれぞれ，図一3一図一 6 に示すものを用いる。付着応力-すべり関係について， 部材, 接合部パネル共にひび割れによる付着応力・付着 剛性の低下は考虑しない。

（b） 有限要素解析にひずみ軟化を考虑した場合，ひ ずみ軟化に伴って開放されるエネルギが，要素の大きさ によって変化するため, 解は要素の大きさに左右され

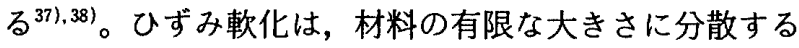

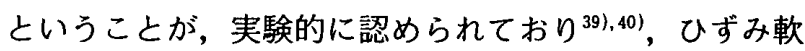
化領域の拡がりに適合した大きさの分割要素を用いた方 が，より実現象に近い解をもたらすことがある。 Bazant ら ${ }^{41)}$ は，代表長さ $l^{*}$ をつ imbricated element を用いる方法を示し，ひずみ軟化は常に長さ $l^{*}$ をもつ 要素のみで評価することにより, 要素分割の影響を取り 除いている。しかし，代表長さ $l^{*}$ の大きさの決定が今 後の課題となっている。これらと同様に，ひずみ軟化を 分割要素法に取り入れる際には, 収束安定性 ${ }^{42)}$ を含めて, いまだに解決されていない種々の問題が存在している。 本解析では，コンクリートのひずみ軟化を，直接的には 扱わないこととする。ここでは，図一3に示すように王 縮ひずみが増加する限りにおいては，応力解除をしない 方法を用いる。除荷された時に，ひずみ軟化領域で仮定 した直線と除荷直線とが交わる場合は,再載荷した時に， この交点での応力より大きな応力を負担し得ないことと し（図一-3中(A)，ひずみ軟化領域で仮定した直線と除 荷直線とが交わらない場合は, 再載荷時点での応力より 大きな応力を負担し得ないこととする (図一 3 中(B)）。

4）座標系と変位増分ベクトル

（a）絶対座標系 $X ， Y$ 軸ならびに，部材要素と共に 移動する要素座標系 $x, y$ 軸を定義する。各節点で, 変 位成分として $x, y$ 軸に対応する方向の変位増分 $\Delta u$, $\Delta v$, 回転の増分 $\Delta \theta$ および各々の鉄筋のすべり増分 $\Delta s$ を考える（図一7）。結果として，鉄筋が 4 段の場合， 接合部パネルのない節点 $i$ における変位増分ベクトル $\Delta u_{i}$ および節点力ベクトル $\boldsymbol{f}_{i}$ は，それぞれ

$$
\begin{aligned}
& \Delta \boldsymbol{u}_{i}=\left(\begin{array}{llllllll}
\Delta u & \Delta v & \Delta \theta & \Delta s_{1} & \Delta s_{2} & \Delta s_{3} & \Delta s_{4}
\end{array}\right)^{T} \\
& \boldsymbol{f}_{i}=\left(\begin{array}{llllllll}
f_{x} & f_{y} & f_{m} & f_{1} & f_{2} & f_{3} & f_{4}
\end{array}\right)^{T}
\end{aligned}
$$

の 7 個の成分をもち, 一つの部材要素の両端の節点変位 増分ベクトル $\Delta_{e} u$, 節点力ベクトル $e_{e} f$ は 14 個の成分 をもつことになる。ただし $f_{x}, f_{y}$ は $x, y$ 方向の節点力, $f_{m}$ は節点モーメント, $f_{1}, f_{2}, f_{3}, f_{4}$ は各段の鉄筋に働 く軸方向力である。

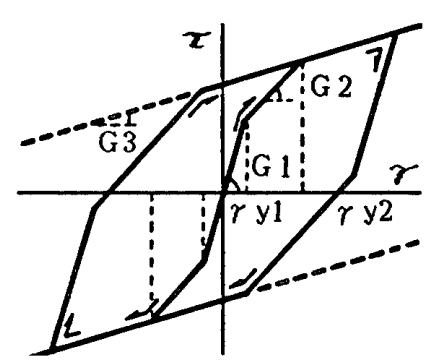

図一6 コンクリートパネルの応カーひずみ関係 ${ }^{33)}$

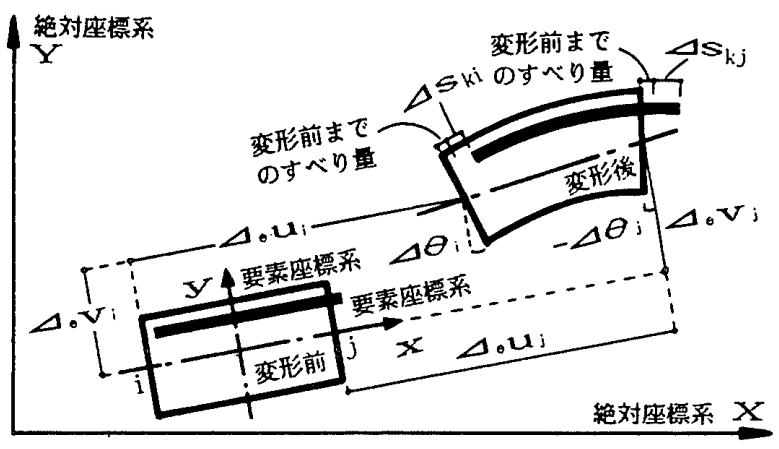

図一7 部材要素の座標系と変位増分

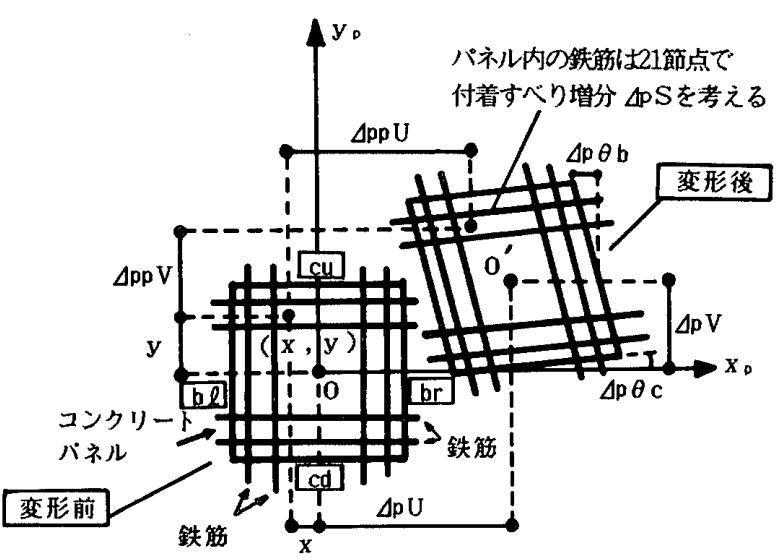

図一8 接合部パネルの坐標系と変位増分

（b）接合部パネルの中心に原点を持つ $x_{p}, y_{p}$ 軸を 定義する。接合部パネル中心点で, 変位成分として $x_{p}$, $y_{p}$ 軸に対応する方向の変位増分 $\Delta_{\rho} u, \Delta_{\rho} v$, はり面, 柱 面の回転の増分 $\Delta_{p} \theta_{b}, \Delta_{p} \theta_{c}$ を考え, 各々の鉄筋に関し ては，接合部パネル内の 19 節点および，接合部パネル 両端面の 2 節点ですべり増分 $\Delta_{p} s$ を考える (図一 8 )。

例えば柱の主筋が 4 段，はりの主筋が 2 段の場合を考 えると一つの接合部パネルの未知変位数は, コンクリー トパネルに関して 4 ，柱筋に関して $21 \times 4=84$ ，はり筋 に関して $21 \times 2=42$ ，の計 130 となる。本解析では，接 合部パネル内の鉄筋に関して，軸方向に 20 要素に分割 した各段の鉄筋要素の 21 の節点のうち, 部材が取り付 く接合部パネル面上の 2 節点におけるすべり増分は残 し，直接外力が作用していないことを利用して内部の 19 の節点でのすべり増分を消去する。よって，一つの 接合部パネルの未知変位数は, コンクリートパネルに関 
して 4 ，柱筋に関して $4 \times 2=8 ， は$ 筋に関して $2 \times 2=$ 4, の計 16 になる。このことにより，接合部パネルのは り面，柱面におけるすべり増分のみで接合部パネル内部 の鉄筋の付着すべりま.で表現でき，鉄筋のすべりが接合 部パネル面から内部に進行してゆく現象を追える。結果 として，柱の主筋が 4 段，はりの主筋が 2 段の場合を例 として示すと，接合部パネルを有する節点における変位 増分ベクトル $\Delta_{p} u_{i}$ および，節点力ベクトル ${ }_{\rho} f_{i}$ はそれ ぞれ，

$$
\begin{aligned}
& \Delta_{\rho} u_{i}=\left(\begin{array}{llll}
\Delta_{\rho} u & \Delta_{\rho} v & \Delta_{\rho} \theta_{b} & \Delta_{\rho} \theta_{c}
\end{array}\right. \\
& \Delta s_{1 c d} \quad \Delta s_{2 c d} \quad \Delta s_{3 c d} \quad \Delta s_{4 c d} \\
& \Delta s_{1 c u} \quad \Delta s_{2 c u} \quad \Delta s_{3 c u} \quad \Delta s_{4 c u} \\
& \begin{array}{llll}
\Delta s_{1 b l} . \Delta s_{2 b l} & \Delta s_{1 b r} & \left.\Delta s_{2 b r}\right)^{r}
\end{array} \\
& { }_{\rho} \boldsymbol{f}_{i}={ }_{p} f_{\dot{x}} \quad{ }_{p} f_{y} \quad{ }_{p} f_{m b} \quad{ }_{p} f_{m c} \\
& f_{1 c d} \quad f_{2 c d} \quad f_{3 c d} \quad f_{1 c d} \\
& f_{1 c u} \quad f_{2 c u} \quad f_{3 c u} f_{4 c u} \\
& \left.f_{1 b l} \quad f_{2 b l} \quad f_{1 b r} f_{2 b r}\right)^{r}
\end{aligned}
$$

の 16 個の成分をもつことになる。ただし， ${ }_{p} f_{x},{ }_{\rho} f_{y}$ は $x_{\rho}, y_{p}$ 方向の節点力, ${ }_{\rho} f_{m b},{ }_{\rho} f_{m c}$ はパネルモーメント, $f_{1 c d} \sim f_{2 b r}$ は各段の鉄筋に働く軸方向力であり, $c d$, $b l, c u, b r$ は図一8中の記号に対応している。有限要 素法を用いて，接合部パネルを縦 4 分割，横 4 分割する と $5 \times 5 \times 2=50$ 自由度となる。本解析では, パネルのせ ん断変形を一様と考えているので内部鉄筋を 20 要素に 分割しても，上述したように 16 自由度で接合部の挙動 を表せる。

\section{2 解析法の概要}

本論文で用いる非線形解析法は，ポテンシャルエネル ギ増分の停留原理に基づいた増分法である。以下に展開 をするように，ポテンシャルエネルギ増分を，変位増分 の二次形式によって表されたひずみエネルギ増分と外力 を受けている部分が変位することによって失う外力のポ テンシャルエネルギの差として考える。これに，二次形 式の変分原理を応用して増分形の方程式を導き, Step by Step 法と Iteration 法によって弾塑性解析を行う。

連立一次方程式の誘導，ブロックチャートなどは文献 35）と同様であるので省略するが，全構造体に対する釣 合方程式は（1）式のようになる。

$$
{ }_{g} K \cdot \Delta_{g} u+{ }_{g} f_{i n}-{ }_{g} f_{e x}=0 \text {. }
$$

ただし，

$$
{ }_{g} K=\sum_{e=1}^{m}{ }_{e} L^{-1^{r}} \cdot{ }_{e} K \cdot{ }_{e} L^{-1}+\sum_{p=1}^{n}{ }_{p} L^{-1^{T}} \cdot{ }_{\rho} K \cdot{ }_{p} L^{-1}
$$

：全構造体の剛性マトリックス

$m:$ 全部材要素数

$n$ : 全接合部パネル数

${ }_{e} \boldsymbol{L}^{-1}$ : 部材要素と全構造体間の座標変換マトリッ

クス
${ }_{e} \boldsymbol{K}: \S 3$. で求められる各部材要素の剛性マト リックス

${ }_{\rho} L^{-1}$ : 接合部パネルと全構造体間の座標変換マト リックス

${ }_{0} K: \S 4$. で求められる各接合部パネルの剛性マ トリックス

$\Delta_{g} u ：$ 全構造体の変位増分ベクトル

${ }_{g} f_{i n}=\sum_{e=1}^{m} e^{-1^{T}} \cdot{ }_{e} f_{i n}+\sum_{\rho=1}^{n}{ }_{\rho} L^{-1^{T}} \cdot{ }_{p} f_{i n}$

：全構造体の内部応力に釣合うために必要な 節点内力ベクトル

${ }_{e} \boldsymbol{f}_{i n}: \S 3$. で求められる増分形算前の内部応力に 釣り合う各部材要素の節点内力ベクトル

${ }_{\rho} f_{i n}: \S 4$. で求められる増分形算前の内部応力に 釣り合う各接合部パネルの内力ベクトル

${ }_{g} f_{e x}$ : 全構造体に作用する外力ベクトル

§3. 鉄筋コンクリート部材の各部材要素の剛性マト リックスと節点内カベクトル

\section{1 変位増分関数}

部材要素の $x$ 軸方向変位增分 $\Delta u$ を $x$ の一次式, $y$ 軸方向変位増分 $\Delta v$ を $x$ の三次式，鉄筋とコンクリー トの間のすべり増分 $\Delta s$ を $x$ の一次式の関数で表す。 鉄筋 4 段の場合について示すと（4）式のようになる。

$$
\begin{aligned}
& \Delta u=\alpha_{1}+\alpha_{2} x \\
& \Delta v=\alpha_{3}+\alpha_{4} x+\alpha_{5} x^{2}+\alpha_{6} x^{3} \\
& \Delta \theta=\quad \alpha_{4}+2 \alpha_{5} x+3 \alpha_{6} x^{2} \\
& \Delta s_{1}=\alpha_{7}+\alpha_{8} x \\
& \Delta s_{2}=\alpha_{9}+\alpha_{10} x \\
& \Delta s_{3}=\alpha_{11}+\alpha_{12} x \\
& \Delta s_{4}=\alpha_{13}+\alpha_{14} x
\end{aligned}
$$

ただし，

$\alpha=\left\{\begin{array}{llllllllllllll}\alpha_{1} & \alpha_{2} & \alpha_{3} & \alpha_{4} & \alpha_{5} & \alpha_{6} & \alpha_{7} & \alpha_{8} & \alpha_{9} & \alpha_{10} & \alpha_{11} & \alpha_{12} & \alpha_{13} & \alpha_{14}\end{array}\right\}^{T}$ : 変位増分関数の未定係数ベクトル

(4) 式において, $x$ に部材要素の両端の座標 $x=\frac{1}{2} l$, $x=-\frac{1}{2} l(l$ は部材要素の長さ) を代入することにより 変位增分ベクトル $\Delta_{e} u$ は末定係数べクトル $\alpha$ で表せる。 この関係から， $\boldsymbol{\alpha}$ は $\Delta_{e} \boldsymbol{u}$ の線形結合で表せる ${ }^{35) 。 ~}$

3.2 部材要素内部の変位増分

要素座標系 $x$ 軸上の点 $(x, 0)$ を通り $x$ 軸に垂直な断 面を考える。 $x$ 軸上の点 $(x, 0)$ における $x$ 軸， $y$ 軸に対 応した方向の変位増分をそれぞれ $\Delta u, \Delta v$ とし回転の 変位增分を $\Delta \theta$ とする。この断面内における $k$ 段目の 鉄筋とコンクリートの間のすべり増分を $\Delta s_{k}$ とする。

1) コンクリート

コンクリート要素に関し，断面内の任意の点 $(x, y)$ の $x, y$ 方向の変位增分および, 回転の変位増分 $\left(\Delta_{c} u\right.$, $\left.\Delta_{c} v, \Delta_{c} \theta\right)$ は ( 5 ) 式のように表すことができる。 


$$
\begin{aligned}
& \Delta_{c} u=\Delta u-y \frac{d \Delta v}{d x} \\
& \Delta_{c} v=\Delta v \\
& \Delta_{c} \theta=\Delta \theta
\end{aligned}
$$

2) 鉄 筋

この断面内の $k$ 段目にある鉄筋 $\left(x, y_{k}\right)$ に関して,$x$ 方向の変位増分および，鉄筋とコンクリートの間のすべ り増分 $\left(\Delta_{s} u_{k}, \Delta s_{k}\right)$ は $(6)$ 式のように表せる。

$$
\left.\begin{array}{l}
\Delta_{s} u_{k}=\Delta u-y_{k} \frac{d \Delta v}{d x}+\Delta s_{k} \\
\Delta s_{k}=\Delta s_{k}
\end{array}\right\}
$$

3.3 部材要素内部のひずみ増分

（4）式の変位増分を微分し，各項を加算することに より，コンクリート要素の軸方向ひずみ増分 $\Delta_{c} \varepsilon_{x}$ およ び，断面内の $k$ 段目の鉄筋要素の軸方向ひずみ増分 $\Delta_{s} \varepsilon_{x k}$ を求めることができる。

3.4 一つの部材要素に蓄えられるひずみエネルギ増分 変位増分によって一つの部材要素に蓄えられるひずみ エネルギ増分 $\Delta_{e} U$ は，その Step またはIteration の計 算を行う直前に生じている応力がひずみ増分によってな すひずみエネルギ増分 [応力メひずみ増分] と，ひずみ 増分によって生ずる応力増分がひずみ増分によってなす

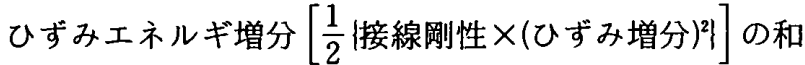
として（7）式のように表すことができる。（7）式は, コンクリートの応力, 鉄筋の応力, 付着応力に関する項 を含んでいる。

$$
\begin{aligned}
\Delta_{e} U= & \int_{l} \int_{A}{ }_{c} \sigma_{x} \cdot \Delta_{c} \varepsilon_{x} d A d x+\frac{1}{2} \int_{l} \int_{A}{ }_{c} E\left(\Delta_{c} \varepsilon_{x}\right)^{2} d A d x \\
& +\sum_{k=1}^{n_{s}} \int_{l}{ }_{s} \sigma_{x k} \cdot{ }_{s} a_{k} \cdot \Delta_{s} \varepsilon_{x k} d x \\
& +\frac{1}{2} \sum_{k=1}^{n_{s}} \int_{l} E_{s} E_{k} \cdot{ }_{s} a_{k}\left(\Delta_{s} \varepsilon_{x k}\right)^{2} d x \\
& +\sum_{k=1}^{n_{s}} \int_{l} \psi_{k} \cdot \tau_{k} \cdot \Delta s_{k} d x \\
& +\frac{1}{2} \sum_{k=1}^{n_{s}} \int_{l} \psi_{k} \cdot K_{k}\left(\Delta s_{k}\right)^{2} d x \ldots \ldots \ldots \ldots(7)
\end{aligned}
$$

ただし， $A$ : 要素の断面積

$l:$ 部材要素の長さ

${ }_{c} E:$ コンクリート要素の応力ーひずみ関係にお ける接線剛性

${ }_{c} \sigma_{x}:$ : ンクリート要素の軸方向応力度

${ }_{s} E:$ 鉄筋要素の応力ーひずみ関係における接線 剛性

$\psi:$ 鉄筋要素の周長

${ }_{s} a:$ 鉄筋要素の断面積

${ }_{s} \sigma_{x}:$ 鉄筋要素の軸方向応力度

$K$ : 付着応力ーひずみ関係における接線剛性

$\tau$ : 鉄筋要素の付着応力度

$n_{s}:$ 鉄筋の段数

\section{$k: k$ 段目の鉄筋であることを表す}

3.5 各部材要素の剛性マトリックスおよび節点内力 ベクトル

(4)，（7）式より一つの部材要素に蓄えられるひず みエネルギ増分 $\Delta_{e} U$ は，末定係数を消去することによ り，（8）式で表すことができる。

$$
\Delta_{e} U=\Delta_{e} u^{r} \cdot{ }_{e} f_{l n}+\frac{1}{2} \Delta_{e} u^{T} \cdot{ }_{e} K \cdot \Delta_{e} u \cdot
$$

ただし， $\Delta_{e} \boldsymbol{u}$ : 各部材要素の変位增分ベクトル この $\boldsymbol{f}_{i n}, e_{e} \boldsymbol{K}$ が, ある外力, 変形を受けた構造物の今の Step から次の Step への計算に必要な部材要素の節点内 カベクトルと魝性マトリックスである。

§4. 接合部パネルの剛性マトリックスと内カベクト ル

4.1 コンクリートパネル

1) コンクリートパネルのせん断ひずみ増分

コンクリートパネルはせん断変形を起こすものとす る。接合部パネルの中心に原点を持つ $x_{\rho}, y_{\rho}$ 軸を図一8 のように定義する。接合部パネルのせん断ひずみ増分 $\Delta \gamma$ は, 柱面の回転増分とはり面の回転増分の差として 表せる。

$$
\Delta \gamma=\Delta_{p} \theta_{c}-\Delta_{p} \theta_{b}
$$

ただし， $\Delta_{\rho} \theta_{c}$ : 柱面の回転増分

$\Delta_{\rho} \theta_{b}:$ はり面の回転増分

2）一つのコンクリートパネルに蓄えられるひずみエ ネルギ増分

変位増分によってコンクリートパネルに蓄えられるひ ずみエネルギ増分 $\Delta_{p p} U$ は，3.4 と同様にして (10) 式 のように表すことができる。

$$
\begin{aligned}
\Delta_{p \rho} U & =\Delta_{\rho p} U_{1}+\Delta_{p p} U_{2} \\
& =\int_{v} \tau \cdot \Delta \gamma d v+\frac{1}{2} \int_{v} G(\Delta \gamma)^{2} d v
\end{aligned}
$$

ただし， $v$ : コンクリートパネルの体積

$G ：$ コクリートパネルの応力ーひずみ関係に おける接線剛性

$\tau$ ：コンクリートパネルのせん断応力度

3）コンクリートパネルの剛性マトリックスと内力ベ クトル

$\Delta_{p \rho} U_{1}, \Delta_{p \rho} U_{2}$ は，(11)，(12）式のように計算できる。

$$
\begin{aligned}
\Delta_{\rho \rho} U_{1} & =\int_{v} \tau \cdot \Delta \gamma d v=\int_{v} \tau\left(\Delta_{\rho} \theta_{c}-\Delta_{\rho} \theta_{b}\right) d v \\
& =\left(\begin{array}{ll}
\Delta_{\rho} \theta_{b} & \left.\Delta_{\rho} \theta_{c}\right)
\end{array}\right)
\end{aligned}
$$$$
=\left(\begin{array}{ll}
\Delta_{p} \theta_{b} & \Delta_{\rho} \theta_{c}
\end{array}\right)_{p p} f_{l n}
$$

$$
\begin{aligned}
\Delta_{\rho p} U_{2} & =\frac{1}{2} \int_{v} G(\Delta \gamma)^{2} d v=\frac{1}{2} \int_{v} G\left(\Delta_{\rho} \theta_{c}-\Delta_{\rho} \theta_{b}\right)^{2} d v \\
= & \frac{1}{2}\left(\begin{array}{lll}
\Delta_{\rho} \theta_{b} & \Delta_{\rho} \theta_{c}
\end{array}\right)\left(\begin{array}{rr}
B D t G & -B D t G \\
-B D t G & B D t G
\end{array}\right)\left(\begin{array}{l}
\Delta_{p} \theta_{b} \\
\Delta_{p} \theta_{c}
\end{array}\right)
\end{aligned}
$$




$$
=\frac{1}{2}\left(\begin{array}{ll}
\Delta_{\rho} \theta_{b} & \Delta_{p} \theta_{c}
\end{array}\right) \cdot{ }_{\rho \rho} K\left(\begin{array}{c}
\Delta_{\rho} \theta_{b} \\
\Delta_{\rho} \theta_{c}
\end{array}\right)
$$

ただし，B：コンクリートパネルの幅

$$
\begin{array}{r}
D: \text { : コンクリートパネルの高さ } \\
t: \text { :コンクリートパネルの厚さ }
\end{array}
$$

この ${ }_{\rho p} f_{i n,}{ }_{\rho} K \boldsymbol{K}$ が, ある外力, 変形を受けた構造物の今 のStep から次の Step への計算に必要なコンクリート パネルの内力ベクトルと剛性マトリックスである。

\section{2 接合部パネル内鉄筋}

1）変位増分関数

接合部パネル内の鉄筋は先に述べたように，各段のは り筋・柱筋について材軸方向に 20 要素に分割する。こ の各要素について，鉄筋とコンクリートの間のすベり増 分を一次式で表す。

[はり筋] $\Delta_{\rho} s_{b}=\beta_{b_{1}}+\beta_{b_{2}} x$

[柱筋] $\quad \Delta_{p} s_{c}=\beta_{c_{1}}+\beta_{c_{2}} y$

ただし， $\beta_{b_{1}}, \beta_{b_{2}}, \beta_{c_{1}}, \beta_{c_{2}}$ は, 末定係数であるが, 各鉄 筋要素の両端のすべり増分で表すことができる。

2）接合部パネル内鉄筋の変位增分

接合部パネル内の $x_{p}$ 軸から $y$ の位置にあるはり筋の $x_{p}$ 軸方向変位増分 $\Delta_{\rho s} u_{b}, y_{p}$ 軸から $x$ の位置にある柱 筋の $y_{p}$ 軸方向変位增分 $\Delta_{\rho s} v_{c}$ は (14), (15) 式のよう に表せる。

[はり筋] $\Delta_{\rho s} u_{b}=\Delta_{\rho} u-y \Delta_{\rho} \theta_{b}+\Delta_{\rho} s_{b}$

[柱筋]

ただし， $\Delta_{p} u$ : 接合部パネル中心点の $x_{p}$ 軸方向変位増 分

$\Delta_{p} v:$ 接合部パネル中心点の $y_{p}$ 軸方向変位增 分

$\Delta_{p} s_{b}:$ コンクリートとはり筋の相対すべり増分

$\Delta_{\rho} s_{c}:$ コンクリート之柱筋の相対すべり増分

3）接合部パネル内鉄筋のひずみ増分

(14)，(15）式より接合部パネル内はり筋の軸方向ひ ずみ増分 $\Delta_{\rho s} \varepsilon_{b}$ および，接合部パネル内柱筋の軸方向ひ ずみ増分 $\Delta_{p s} \varepsilon_{c}$ は以下のように求めることができる。

[はり筋] $\Delta_{\rho s} \varepsilon_{b}=\frac{\partial \Delta_{\rho s} u_{b}}{\partial x}=\frac{d \Delta_{\rho} s_{b}}{d x}$

[柱筋]

$$
\Delta_{p s} \varepsilon_{c}=\frac{\partial \Delta_{\rho s} v_{c}}{\partial y}=\frac{d \Delta_{\rho} s_{c}}{d y}
$$

4）接合部パネル内鉄筋要素に蓄えられるひずみエネ ルギ増分

変位增分が生じることにより, 接合部パネル内のはり 筋要素に蓄えられるひずみエネルギ増分および，付着す ベりによるエネルギ增分 $\Delta_{p s} U_{b}$ は， 3.4 と同様にして

（18）式のように表すことができる。

$$
\begin{aligned}
\Delta_{\rho s} U_{b}= & \sum_{k=1}^{n_{s}} \int_{l}{ }_{\rho s} \sigma_{b k}{ }_{\rho s} a_{b k} \cdot \Delta_{\rho s} \varepsilon_{b k} d x \\
& +\frac{1}{2} \sum_{k=1}^{n_{s}} \int_{l} \int_{\rho s} E_{b k^{*} \cdot{ }_{\rho s}} a_{b k}\left(\Delta_{\rho s} \varepsilon_{b k}\right)^{2} d x
\end{aligned}
$$

$$
\begin{aligned}
& +\sum_{k=1}^{n_{s}} \int_{l}{ }_{\rho s} \psi_{b k} \cdot{ }_{\rho s} \tau_{b k} \cdot \Delta_{\rho} s_{b k} d x \\
& +\frac{1}{2} \sum_{k=1}^{n_{s}} \int_{l}{ }_{\rho s} \psi_{b k^{*} \cdot{ }_{\rho s}} K_{b k}\left(\Delta_{\rho} s_{b k}\right)^{2} d x \cdots \cdots
\end{aligned}
$$

接合部パネル内の柱筋要素に蓄えられるひずみエネルギ 增分 $\Delta_{p s} U_{c}$ についても，同樣に求められる。

$$
\begin{aligned}
\Delta_{p s} U_{c}= & \sum_{k=1}^{n_{s}} \int_{l}{ }_{p s} \sigma_{c k} \cdot{ }_{p s} a_{c k} \cdot \Delta_{p s} \varepsilon_{c k} d x \\
& +\frac{1}{2} \sum_{k=1}^{n_{s}} \int_{l} E_{c s} E_{c k} \cdot{ }_{p s} a_{c k}\left(\Delta_{p s} \varepsilon_{c k}\right)^{2} d x \\
& +\sum_{k=1}^{n_{s}} \int_{l}{ }_{p s} \psi_{c k} \cdot{ }_{p s} \tau_{c k} \cdot \Delta_{p} s_{c k} d x \\
& +\frac{1}{2} \sum_{k=1}^{n_{s}} \int_{l}{ }_{l s} \psi_{c k}{ }^{\cdot}{ }_{p s} K_{c k}\left(\Delta_{\rho} s_{c k}\right)^{2} d x \cdots
\end{aligned}
$$

ただし $, \quad l:$ 鉄筋要素の長さ

${ }_{p s} \tau$ : 鉄筋要素の付着応力度

${ }_{\rho s} E:$ 鉄筋要素の応力ーひずみ関係における接線 㣚性

${ }_{{ }_{s}} \psi:$ 鉄筋要素の周長

${ }_{p s} a:$ 鉄筋要素の断面積

${ }_{p s} \sigma:$ 鉄筋要素の軸方向応力度

${ }_{\rho s} K$ : 付着応力ーひずみ関係における接線剛性

$n_{s}:$ 鉄筋の段数

$k: k$ 段目の鉄筋であることを表す

$b$ : はり筋であることを表す

$c ：$ 柱筋であることを表す

5）接合部パネル内鉄筋要素の剛性マトリックスおよ び節点内力ベクトル

(13)，(18)，(19）式より，接合部パネル内はり筋要素 に蓄えられるひずみエネルギ増分 $\Delta_{\rho s} U_{b}$ および接合部 パネル内柱筋要素に蓄えられるひずみエネルギ増分 $\Delta_{p s} U_{c}$ は，末定係数を消去することにより，(20)，(21) 式のように表すことができる。

$$
\begin{aligned}
& \Delta_{p s} U_{b}=\Delta_{p s} u_{b}^{T} \cdot{ }_{\rho s} f_{i n b}+\frac{1}{2} \Delta_{p s} u_{b}^{T} \cdot{ }_{\rho s} K_{b} \Delta_{\rho s} u_{b} \cdots(20) \\
& \Delta_{\rho s} U_{c}=\Delta_{p s} u_{c}^{T} \cdot{ }_{\rho s} f_{i n c}+\frac{1}{2} \Delta_{\rho s} u_{c}^{T} \cdot{ }_{\rho s} K_{c} \Delta_{\rho s} \boldsymbol{u}_{c} \cdots(21)
\end{aligned}
$$

[はり筋]

$$
\begin{aligned}
\Delta_{\rho s} u_{b}= & \left\{\Delta_{\rho} s_{b_{11}} \Delta_{\rho} s_{b_{2 l}} \Delta_{\rho} s_{b_{3 i}} \Delta_{\rho} s_{b_{b l}}\right. \\
& \left.\Delta_{\rho} s_{b_{1 j}} \Delta_{\rho} s_{b_{2 j}} \Delta_{\rho} s_{b_{3 j}} \Delta_{\rho} s_{b_{b 4}}\right\}^{T}
\end{aligned}
$$

[柱筋]

$$
\begin{aligned}
\Delta_{\rho s} \boldsymbol{u}_{c}= & \left\{\Delta_{\rho} s_{c_{1 t}} \Delta_{\rho} s_{c_{2 l}} \Delta_{\rho} s_{c_{3 t}} \Delta_{\rho} s_{c_{4 t}}\right. \\
& \Delta_{\rho} s_{c_{1 j}} \Delta_{\rho} s_{c_{2 j}} \Delta_{\rho} s_{c_{3 j}} \Delta_{\rho} s_{c_{s j} j} T^{T}
\end{aligned}
$$

: 接合部パネル内鉄筋要素の変位增分ベクト ル

$i, j$ は両端の節点名を表す。

${ }_{\rho s} \boldsymbol{f}_{i n b},{ }_{\rho s} \boldsymbol{f}_{i n c},{ }_{\rho s} \boldsymbol{K}_{b},{ }_{\rho s} \boldsymbol{K}_{c}$ は，ある外力，変形を受けた構 造物の今の Step から次の Step への計算に必要な接合 部パネル内鉄筋要素の内力ベクトルと剛性マトリックス である。 
4.3 接合部バネルの剛性マトリックスと内力ベクトル 増分計算前の内部応力に釣り合う各接合部パネルの内 カベクトル ${ }_{p} \boldsymbol{f}_{\text {in }}$ および, 各接合部パネルの剛性マトリッ クス。 $K$ は, (11), (12), (20), (21) 式から (22), (23) 式のように表せる。

$$
\begin{aligned}
& { }_{\rho} f_{i n}={ }_{p \rho} f_{i n}+{ }_{\rho s} f_{i n b}^{\prime}+{ }_{p s} f_{i n c}^{\prime} \\
& { }_{p} K={ }_{p p} K+{ }_{p s} K_{b}^{\prime}+{ }_{p s} K_{c}^{\prime} \cdots
\end{aligned}
$$

ただし， ${ }_{p s} f_{i n b, p s}^{\prime} f_{i n c, p s}^{\prime} K_{b, p s}^{\prime} K_{c}^{\prime}$ は, (20), (21) 式の ${ }_{p s} f_{i n b},{ }_{p s} f_{i n c},{ }_{p s} K_{b},{ }_{p s} K_{c}$ から, 接合部パネル内の各鉄筋 の 19 節点でのすべり増分を消去して求めた接合部パネ ル内鉄筋要素の内力ベクトルと剛性マトリックスであ る。

4.4 接合部パネルを有する部材の剛性マトリックス と内力ベクトル

1）部材の変位増分と接合部パネルの変位増分の連続 条件

接合部パネルの中心点 $\mathrm{P}$ の変位增分 $\Delta_{p} u=\left(\Delta_{p} u\right.$, $\left.\Delta_{\rho} v, \Delta_{\rho} \theta_{b}, \Delta_{\rho} \theta_{c}\right)^{T}$ とはり面の中央点 B の変位增分 $\Delta u_{b}$ $=\left(\Delta u_{b}, \Delta v_{b}, \Delta \theta_{b}\right)^{r}$ の連続条件は（24）式のように表せ る(図一9)。

$$
\left[\begin{array}{l}
\Delta u_{b} \\
\Delta v_{b} \\
\Delta \theta_{b}
\end{array}\right]=\left[\begin{array}{llll}
1 & \cdot & \cdot & \cdot \\
\cdot & 1 & \cdot & l_{x} \\
\cdot & \cdot & 1 & \cdot
\end{array}\right]\left[\begin{array}{l}
\Delta_{\rho} u \\
\Delta_{\rho} v \\
\Delta_{\rho} \theta_{b} \\
\Delta_{\rho} \theta_{c}
\end{array}\right]
$$$$
=\boldsymbol{R}_{b} \cdot \Delta_{\rho} u
$$

接合部パネルの中心点 $\mathrm{P}$ の変位增分と柱面の中央点 $\mathrm{C}$ の変位增分 $\Delta \boldsymbol{u}_{c}=\left(\Delta u_{c}, \Delta v_{c}, \Delta \theta_{c}\right)^{T}$ の連続条件は, $(25)$ 式のように表せる。

$$
\left[\begin{array}{l}
\Delta u_{c} \\
\Delta v_{c} \\
\Delta \theta_{c}
\end{array}\right]=\left[\begin{array}{cccc}
1 & \cdot & -l_{y} & \cdot \\
\cdot & 1 & \cdot & \cdot \\
\cdot & \cdot & \cdot & 1
\end{array}\right]\left[\begin{array}{l}
\Delta_{p} u \\
\Delta_{\rho} v \\
\Delta_{\rho} \theta_{b} \\
\Delta_{p} \theta_{c}
\end{array}\right]
$$$$
=\boldsymbol{R}_{\boldsymbol{c}} \cdot \Delta_{\boldsymbol{\rho}} \boldsymbol{u}
$$

ただし， $l_{x}, l_{y}$ は図一 9 の $\mathrm{P}$ 点を原点とした座標で与え る。

2）接合部パネルを有する部材の剛性マトリックスと 内力ベクトル

(24), (25) 式の変換マトリックス $\boldsymbol{R}_{b}$ または $\boldsymbol{R}_{c}$ を, 接合部パネル面における鉄筋のすべりと部材要素両端部 における鉄筋のすべりの連続条件を含めて拡大した変換

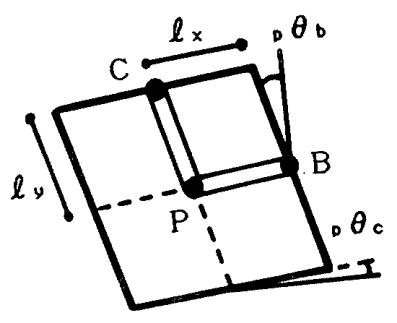

図一9 接合部パネル

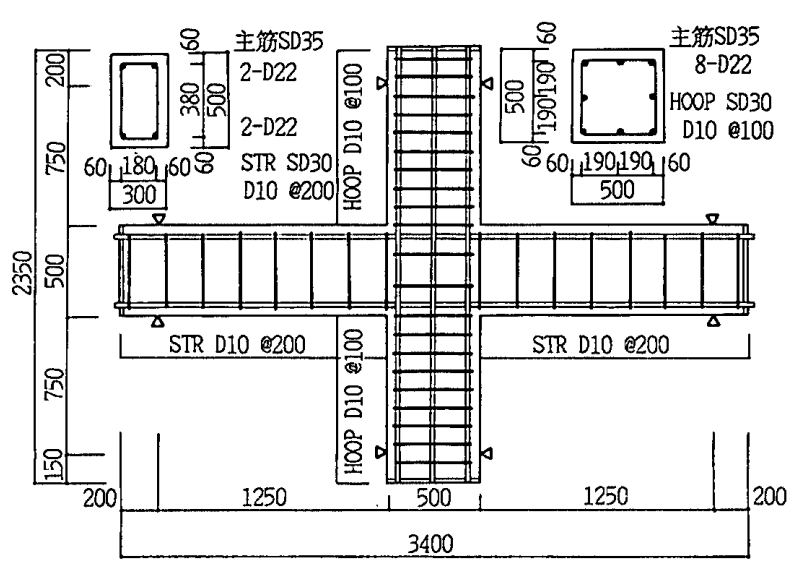

図一10 十字型骨組試験(体 43

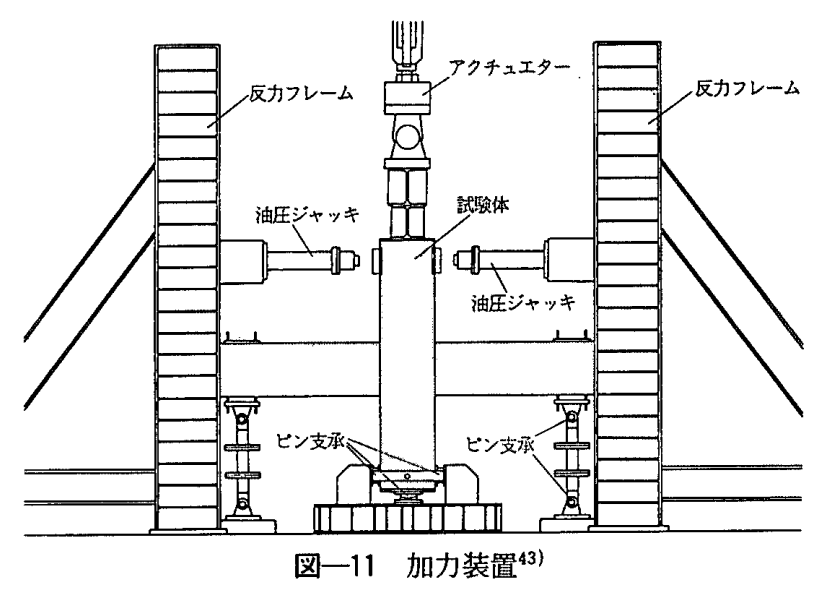

\begin{tabular}{|c|c|c|c|}
\hline $\begin{array}{l}c E=261.0 \\
{ }_{c} \sigma_{B}=271.5 \\
c \varepsilon_{\mathrm{B}}=0.0027 \\
K_{1}=4.0(9.0) \\
K_{2}=0.2 \\
K_{3}=0.05 \\
\tau_{y 1}=40 .(1000 .) \\
\tau_{y 2}=5 . \\
() \text { 内は付着弾性 }\end{array}$ & $\begin{array}{l}\mathrm{t} / \mathrm{cm}^{2} \\
\mathrm{~kg} / \mathrm{cm}^{2} \\
\mathrm{t} / \mathrm{cm}^{3} \\
\mathrm{t} / \mathrm{cm}^{3} \\
\mathrm{t} / \mathrm{cm}^{3} \\
\mathrm{~kg} / \mathrm{cm}^{2} \\
\mathrm{~kg} / \mathrm{cm}^{2} \\
\text { の場合 }\end{array}$ & $\begin{aligned} \mathrm{s} \mathrm{E} & =2100 . \\
\mathrm{E}_{D} & =21 . \\
\alpha & =10.5 \\
{ }_{\mathrm{S}} \sigma_{y} & =3840 . \\
\mathrm{G}_{1} & =60 . \\
\mathrm{G}_{2} & =48 . \\
\mathrm{G}_{3} & =12 . \\
r_{y_{1}} & =0.0005 \\
r_{y_{2}} & =0.003\end{aligned}$ & $\begin{array}{c}t / \mathrm{cm}^{2} \\
t / \mathrm{cm}^{2} \\
t / \mathrm{cm}^{2} \\
\mathrm{~kg} / \mathrm{cm}^{2} \\
t / \mathrm{cm}^{2} \\
t / \mathrm{cm}^{2} \\
t / \mathrm{cm}^{2}\end{array}$ \\
\hline
\end{tabular}

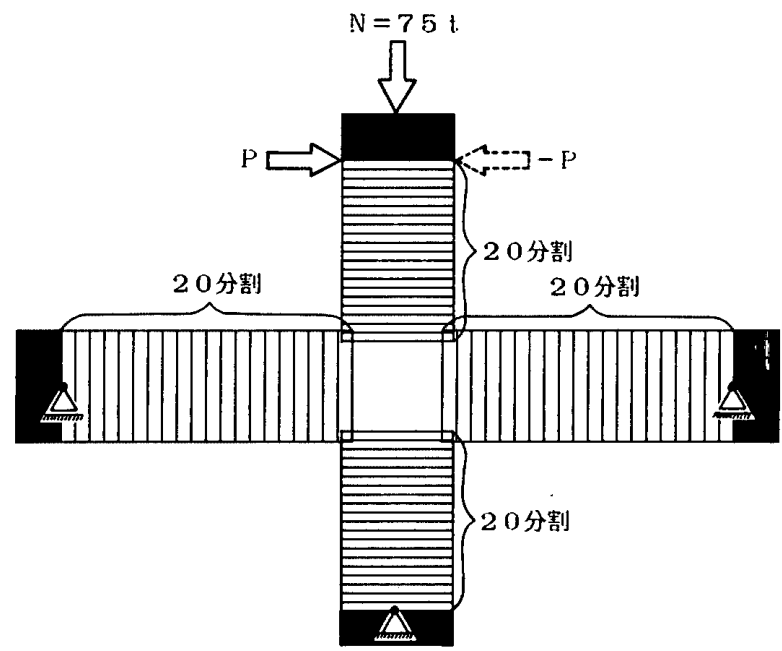

図一12 解析モデル

表一1 解析に用いた諸定数 
マトリックス $\boldsymbol{R}$ と部材要素の剛性マトリックス ${ }_{e} \boldsymbol{K}$ お よび節点内力ベクトル ${ }_{e} f_{i n}$ を用いることにより，接合部 パネルを有する部材の㴊性マトリックス ${ }_{e} \boldsymbol{K}^{\prime}$ および内 カベクトル ${ }_{e} f_{i n}^{\prime}$ は, (26), (27) 式のように表すことが できる。

$$
\begin{aligned}
& { }_{e} \boldsymbol{K}^{\prime}=\boldsymbol{R}^{\prime{ }^{T}} \cdot{ }_{e} \boldsymbol{L}^{-1^{\top}} \cdot{ }_{e} \boldsymbol{K} \cdot{ }_{e} \boldsymbol{L}^{-1} \cdot \boldsymbol{R}^{\prime} \\
& \boldsymbol{f}^{\prime}{ }_{i n}=\boldsymbol{R}^{\prime} \cdot{ }_{e} \boldsymbol{L}^{-1^{\top}} \cdot{ }_{e} \boldsymbol{f}_{t n} \ldots \ldots \ldots \ldots
\end{aligned}
$$

ただし， $\boldsymbol{R}^{\prime}$ は，部材要素の $i$ 端に接合部パネルが取り 付く場合, 部材要素の $j$ 端に接合部パネルが取り付く

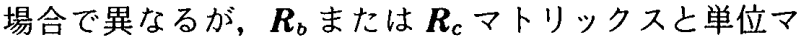
トリックスを対角線上に組み合わせたマトリックスであ る。

(2) 式の ${ }_{e} L^{-1^{r}} \cdot{ }_{e} \boldsymbol{K} \cdot{ }_{e} \boldsymbol{L}^{-1}$ を ${ }_{e} \boldsymbol{K}^{\prime}$ に置き換え, (3) 式 の ${ }_{e} \boldsymbol{L}^{-1^{T}} \cdot{ }_{e} \boldsymbol{f}_{i n}$ をこの ${ }_{e} \boldsymbol{f}_{\text {in }}^{\prime}$ に置き換えることにより，接合 部パネルを有する部材の剛性マトリックスと内力ベクト ルが求められる。

\section{§5. 十字型骨組の数值解析例}

5.1 解析対象および解析モデル

本解析法を用いて十字型骨組の数値解析を行った。対 象物は, 城内ら ${ }^{43)}$ の行った実験のうち試験体記号 NX 1 のものである。図一10に試験体図を示す。実験では, 図一11に示すように柱脚をピン支持，はり先端を上下 変位拘束のピンローラで支持している。柱頭にアクチュ エータにより $75 \mathrm{t}\left(\sigma=30 \mathrm{~kg} / \mathrm{cm}^{2}\right)$ の一定軸力をかけ, 油王ジャッキにより左右から交互に水平力をかけてい

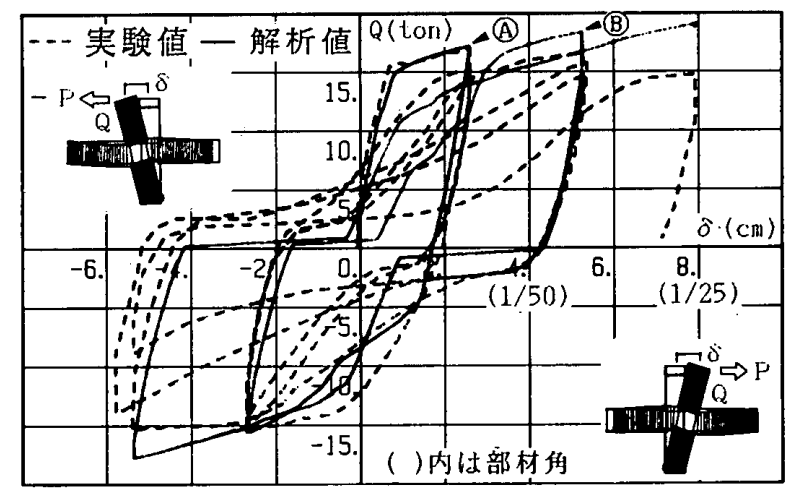

図一13 柱のせん断力-変位関係

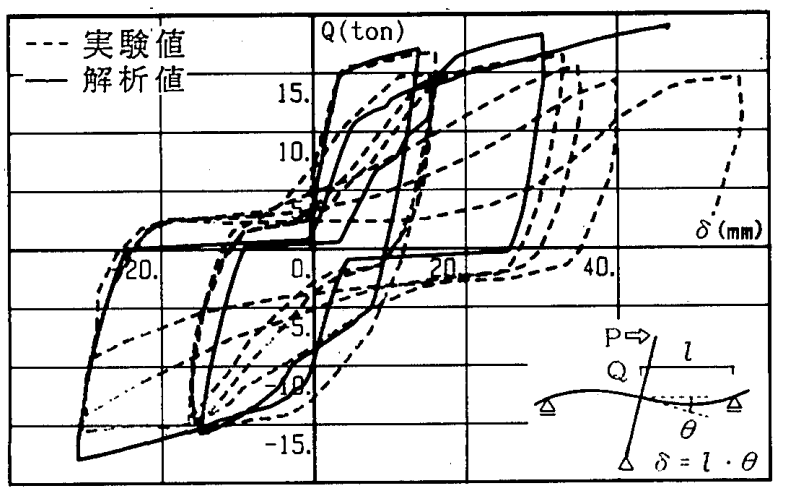

図一14 柱のせん断力ーはりのたわみ関係
る。

図一12に解析モデルおよび分割図を示す。接合部パ ネルは，柱およびはり主筋に囲まれた部分とした。上下 の柱, 左右のはりをそれぞれ 20 の部材要素に分割した。 境界条件は，柱脚をピン支持とし，はり先端をローラ支 持とした。柱頭の加力点より上, 柱脚のピン支持点より 下および，はりのローラ支持点より外側の部材の付着は 常に弾性とした。解析では，実験での繰り返し方を単純 化し， $2 \delta_{y}$ (部材角 $1 / 75$ )，4 $\delta_{y}$ (部材角 $2 / 75$ ）でそれ ぞれ 1 回ずつ繰り返し，その後正側に加力した。解析に 用いた諸定数を表一1に示す。

\section{2 解析結果および考察}

図一 13 に，柱のせん断力と加力点の水平変位の関係
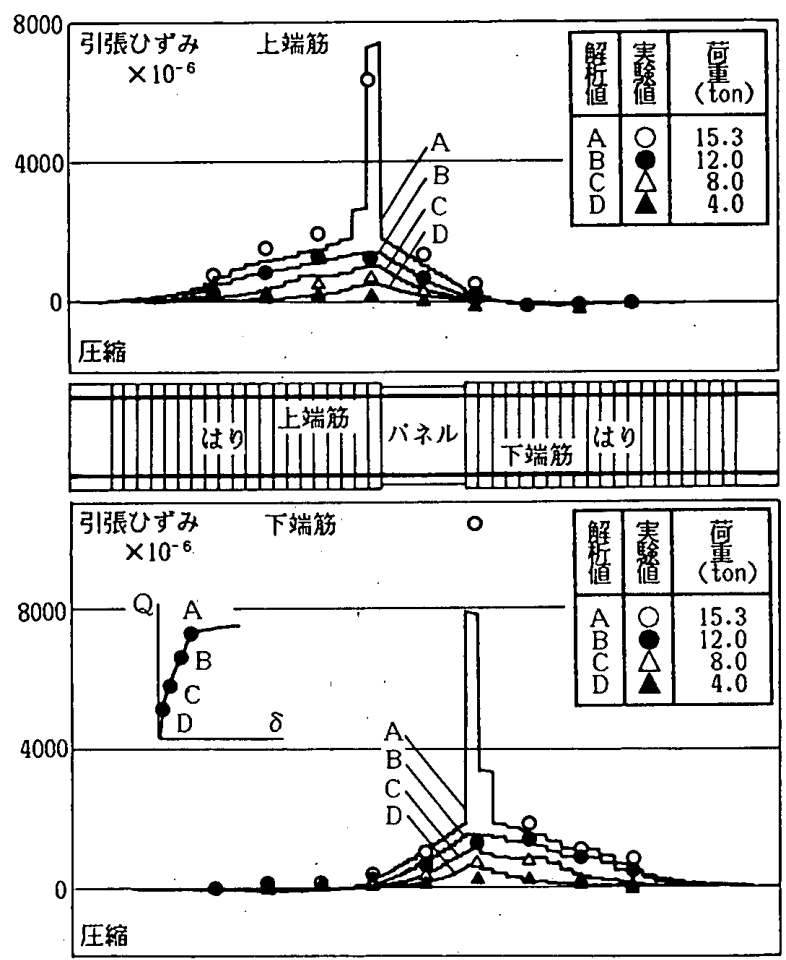

図一15 はり筋のひずみ分布

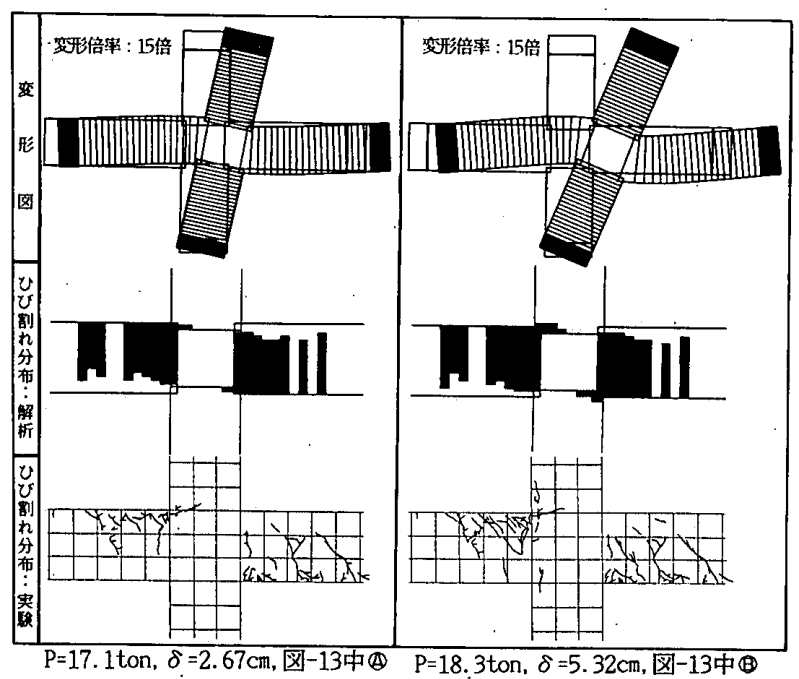

図-16 変形・ひび割れ分布 
を示す。ここでいうせん断力は, 軸力による付加モーメ ントの影響を考虑したものである。実線が解析結果で, 破線が実験結果である。2 $\delta_{y}$ の正側ループでは, 実験結 果と解析結果がよい対応を示している。その後, $2 \delta_{y}$ の 負側ループおよび $4 \delta_{y}$ のループでは, 解析の方がルー プが細っている。これは，コンクリートの応力ーひずみ 関係(図一3)において,一度ひび割れを生じたコンクリー ト要素のひずみが,ひび割れ時のひずみまで達した時に, ひび割れが閉じて応力を負担すると仮定していることが 一つの原因と考えられる。また，今回は接合部パネル内 の降伏付着応力 $\tau_{y 1}$ (図一5) を部材内部と同じとしたが, 王縮力を受ける接合部パネル内の $\tau_{y 1}$ は部材内部より高 く, 柱軸力の影響を受けるなどの報告もあり ${ }^{44)}$,このこ とも一つの原因と考えられる。降伏耐力および，ループ の概形は説明できていると思われる。図一14に，柱の せん断力と, はりの回転角から求めたはりのたわみの関 係を示す。実験では，はり端において柱の回転角を変位 計により測定し，これをはりの回転角としている。図一 13 と同様の傾向にあるものの, ほぼよい対応を示して いるものと思われる。図一15に $2 \delta_{y}$ の正側ループ上の 4 段階においてはり筋のひずみ分布を示す。上に示した ものが上端筋のひずみ分布で，下に示したものが下端筋 のひずみ分布である。実線 $\mathrm{A}, \mathrm{B}, \mathrm{C}, \mathrm{D}$ が解析結果,

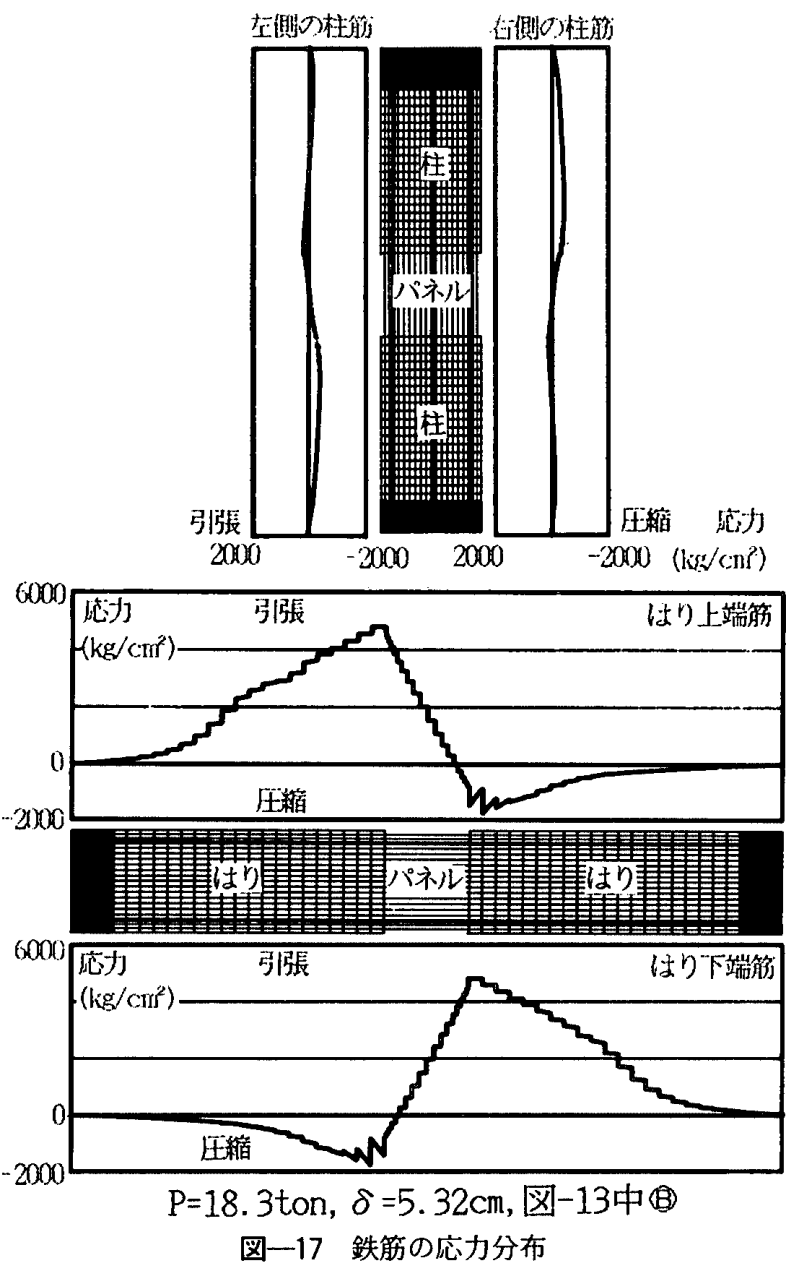

$\bigcirc, \boldsymbol{O}, \Delta, \Delta$ が実験結果であり，両者はよい対応を示 している。また，接合部パネル内部の引張ひずみが荷重 の増加と共に大きくなっていく様子がわかる。図一16 に $2 \delta_{y}\left(P=17.1 \mathrm{ton}, \delta=2.67 \mathrm{~cm}\right.$, 図-13中(A), $4 \delta_{y}$ ( $P=18.3$ ton, $\delta=5.32 \mathrm{~cm}$ ，図一13中(B)）における 変形図，ひび割れ分布図を示す。図一17,18に $4 \delta_{y}$ に おける鉄筋の応力度分布図, 付着応力度分布図を示す。 奏験および解析におけるひび割れの様子は，ほぼよい対 応を示している。また，ひび割れの前後で付着応力度分 布が大きく変化している様子, 部材と接合部パネルの接 触面で付着応力度分布が正負反転している様子が見られ る。

\section{§6. 結 論}

以上, 接合部パネルのせん断変形と接合部パネル内の 鉄筋の付着すべりを考虑しうる鉄筋コンクリート骨組の 分割要素法に関し，その解析法をポテンシャルエネルギ 増分の停留原理を用いて誘導し，これを用いた十字型骨 組の解析例を示した。その結果および考察より以下の事 柄が明らかになった。

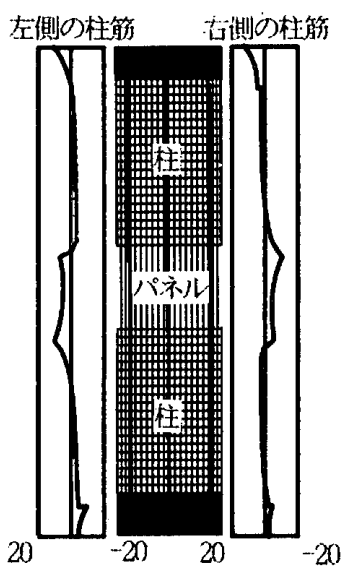

付堵爬力 (kg/ $\left.\mathrm{cm}^{2}\right)$

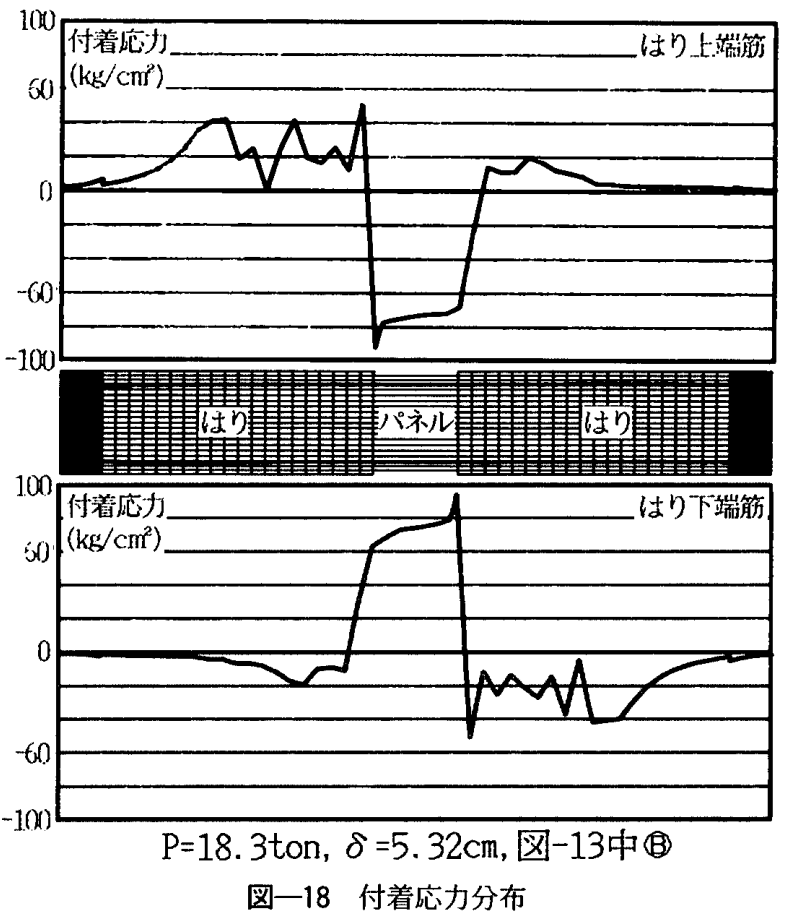




\section{1 結 論}

1）本解析法により,コンクリートのひび割れ・塑性, 鉄筋の降伏・すべり，柱・はり接合部からの鉄筋の抜け 出し・押し込みなどの現象を表すことができる。

2）接合部パネルの導入により部材と柱・はり接合部 内の鉄筋の連続性を満たしながら, 柱・はり接合部のせ ん断変形を考虑できる。

3）解析例として一例を示したに過ぎないが, 荷重一 変位関係および，鉄筋のひずみ分布，ひび割れ分布等に おいて，実験と解析はほぼよい対応を示した。曲げ降伏 型の鉄筋コンクリート骨組に対して，本論で示した解析 法は有効であると思われる。

4）本解析法を用いれば，有限要素法等に比べ未知変 位数が少なく大規模 RC 骨組の計算も可能であると考 える。

\section{2 今後の課題}

鉄筋コンクリート部材の, 斜めひび割れは, 変形性状 に大きな影響を与える。今後，斜めひび割れそのものを 取り扱えるような方法の開発が必要であると考える。

\section{謝 辞}

福井大学助教授・小林克巳博士には, 日頃有益な御指 導を頂いています。(株) 間組・戸田哲雄氏，岩崎昭則 氏には，貴重な実験資料を提供して頂きました。ここに， 心より感謝の意を表します。研究費の一部に文部省科学 研究費を使用しました。関係者各位に御礼申し上げます。

\section{参考文献}

1）広沢雅也, 口之町尚, 後藤暂郎ほか：8階建壁式鉄筋コ ンクリート造アパートの耐震性に関する実大破壊実験 (そ の 1 その 8), 日本建築学会大会学術講演梗概集, 昭和 55 年 9 月, pp. $1669 \sim 1684$

2）後藤哲郎, 広沢雅也, 出下一也, 石塚忠行：8 階建壁式 鉄筋コンクリート造アパートの耐震性に関する実大破壊 実験（その 9 その 10), 日本建築学会大会学術講演梗概 集, 昭和 56 年 9 月, pp. 1695 1698

3）岡本 伸, 芳村 学, 上之薗隆志, 中田慎介：鉄筋コン クリート造実大 7 層建物の建設とその弾性性状（日米共 同耐震実験研究その 1 ), 日本建築学会構造系論文報告集, 第 366 号, 昭和 61 年 8 月, pp. 76 84

4）芳村 学, 上之䓢隆志, 岡本 伸, 中田慎介：鉄筋コン クリート造実大 7 層建物の弾塑性解析と 1 質点置換によ る仮動的実験手法（日米共同耐震実験研究その 2 ), 日本 建築学会構造系論文報告集, 第 372 号, 昭和 62 年 2 月, pp. $55 \sim 64$

5）上之薗隆志, 芳村 学, 岡本 伸, 中田慎介：鉄筋コン クリート造実大 7 層建物の仮動的実験（日米共同耐震実 験研究その 3 ), 日本建築学会構造系論文報告集, 第 377 号, 昭和 62 年 7 月, pp. $64 \sim 72$

6) Kitagawa, Y. and Midorikawa, M. : Dynamic Properties and Response Analysis of a Full-Scale Reinforced Concrete Seven-Story Structure, Jour. of Structural and Construction Engineering (Trans. of AIJ), No.380,
Oct. 1987, pp. $32 \sim 44$

7）梅村 魅, 加藤 勉, 渡部 丹ほか：日米共同大型耐震 実験研究，鉄骨造実大 6 層建物の耐震実験（その $1 \sim$ そ の 14), 日本建築学会大会学術講演梗概集, 昭和 58 年 9 月, pp. 1173 1200

8) Foutch, D.A., Goel, S.C., and Roeder, C. W. : Sesmic Testing of Full-Scale Steel Building-Part I, II , Jour. of Strutural Engng., Proc. of ASCE, Vol. 113, No. 11, Nov. 1987, pp. 2111 2145

9) Ngo, D.," and Scordelis, A.C. : Finite Element Analysis of Reinforced Concrete Beams, Jour. of ACI, March 1967, pp. 152 163

10）黒正清治, 龍口克己：有限要素法による鉄筋コンクリー 卜部材の二次元非線型解析（その 1 仮定および解析方 法), 日本建築学会論文報告集, 第 189 号, 昭和 46 年 11 月, pp. $51 \sim 57$

11）武藤 清, 营野 忠, 宮下 丘, 井上範夫 : 有限要素法 による鉄筋コンクリート部材の 3 次元弾塑性解析（その 1 解析法之数值解析例), 日本建築学会論文報告集, 第 249 号, 昭和 51 年 11 月, pp. 25 34

12）野口 博, 長沼一洋：繰返し荷重を受ける $\mathrm{RC}$ 柱・はり 接合部の非線形解析, 第 2 回 $\mathrm{RC}$ 構造のせん断問題に対 する解析的研究に関するコロキウム, 昭和 58 年 10 月, pp. 283 297

13) Park, R., Kent, D. C., and Sampson, R. A. : Reinforced Concrete Members with Cyclic Loading, Jour. of ST-Div., Proc. of ASCE, Vol.98, No.7, July 1972, pp. $1341 \sim 1360$

14) Park, R., and Sampson, R. A. : Ductility of Reinforced Concrete Column Sections in Seismic Design, Jour. of ACI, Vol. 69, Sept. 1972, pp. 1341 1360

15）岩下恒雄：分割要素法による構造物の 2 次元弾塑性解析, 東京工業大学学位論文, 昭和 42 年 12 月

16）蜜川栄志，青山博之：鉄筋のすべりを考虑した $\mathrm{RC}$ 部材 の解析, 日本建築学会大会学術講演梗概集; 昭和 49 年 10 月, pp. 1153,1154

17）蜜川栄志，青山博之：鉄筋のすべりを考虑した RC 部材 の弾塑性解析, 日本建築学会関東支部研究報告集, 昭和 50 年, pp. $177 \sim 180$

18）谷 資信, 野村設郎, 永坂具也, 平松 晃：鉄筋コンクリー 卜耐震要素の復元力特性（その 4)，日本建築学会論文報 告集, 第 262 号, 昭和 52 年 12 月, pp. 61 72

19）松浦 誠，山本春行：鉄筋コンクリートはり，柱部材の 非線形および時間依存性挙動, 日本建築学会論文報告集, 第 322 号, 昭和 57 年 12 月, pp. $36 \sim 43$

20）小阪義夫, 谷川恭雄, 山田和夫：エンドクロニック理論 による鉄筋コンクリートの非弾性解析一第 1 報解析方法 一, 日本建築学会論文報告集, 第 326 号, 昭和 58 年 4 月, pp. $78 \sim 90$

21）小阪義夫, 谷川恭雄, 山田和夫：エンドクロニック理論 による鉄筋コンクリートの非弾性解析一第 2 報本解析手 法の特徴および解析結果と実験結果との比較検討一, 日 本建築学会論文報告集, 第 330 号, 昭和 58 年 8 月, pp. 9 23

22）市之瀬敏勝：付着すべりを考虑した鉄筋コンクリート骨 組の解析法一鉄筋・付着とも弾性の場合一, 日本建築学 
会論文報告集, 第 327 号, 昭和 58 年 5 月, pp. $61 \sim 71$

23）市之瀬敏勝：付着すべりを考慮した鉄筋コンクリート骨 組の非線形解析法, 日本建築学会諭文報告集, 第 328 号, 昭和 58 年 6 月, pp. $26 \sim 35$

24）上田正生, 土橋由造：軸力を受ける鉄筋コンクリート棒 部材の材料非線形付着すべり解析, 土木学会論文集, 第 360 号, 昭和 60 年 8 月, pp. $71 \sim 80$

25）上田正生，土橋由造：補強筋の付着すべりを考慮した鉄 筋コンクリートはり部材の曲げ変形解析, 土木学会論文 集, 第 372 号, 昭和 61 年 8 月, pp. $55 \sim 64$

26) Otani, S. : Inelastic Analysis of R/C Frame Structures, Jour. of the Structural Division, Proc. of ASCE, Vol. 100, ST7, July 1974, pp. 1433 1449

27）多田利正, 武田寿一：鉄筋コンクリート部材における付 着劣化仮定の解析的研究 (その 1 ), 日本建築学会論文報 告集, 第 351 号, 昭和 60 年 5 月, pp. 22 30

28) Filippou, F.C., Popov, E. P., and Bertero, V.V. : Modeling of R/C Joints under Cyclic Excitations, Jour. of Structural Engng., Proc. of ASCE, Vol. 109, No. 11, Nov. 1983, pp. 2666 2684

29）菅野 忠：柱・梁接合部のせん断変形を考慮した場合の マトリックス法による骨組解析法, 日本建築学会関東支 部研究報告集, 昭和 43 年 6 月, pp. $311 \sim 314$

30）梅村 魁, 滝沢春男, 久保哲夫：構成部材の弾塑性性状 に基づいた，鉄筋コンクリート造骨組の弾塑性地震応答 解析（その1 2), 日本建築学会関東支部研究報告集, 昭和 46 年, pp. 145 152

31）黒正清治, 和田 章, 坂田弘安：鉄筋コンクリート部材 の付着を考虑した曲げ弾塑性解析, 日本建築学会大会学 術講演梗概集, 昭和 58 年 9 月, pp. 1883,1884

32）黒正清治, 和田 章, 坂田弘安：歪軟化領域を有する材 料によって作られた構造物の非線形解析法, 日本建築学 会大会学術講演梗概集, 昭和 59 年 10 月, pp. 2205, 2206

33）黒正清治, 和田 章, 坂田弘安：繰り返し荷重を受ける 鉄筋コンクリート骨組の線材理論に基づいた弾塑性解析 法に関する研究, 第 9 回構造工学における数值解析シン ポジウム諭文集, 昭和 60 年 7 月, pp. 157 162

34）黒正清治, 和田 章, 坂田弘安: 接合部のせん断変形と 鉄筋の付着すべり・降伏を考虑した鉄筋コンクリート骨
組の弾塑性解析法, 日本建築学会大会学術講演梗概集, 昭和 60 年 10 月, pp. 11,12

35）藤本盛久,和田 章, 白方和彦, 小杉 立：筋違付鉄骨ラ一 メンの弾塑性解析に関する研究, 日本建築学会論文報告 集, 第 209 号, 昭和 48 年 7 月, pp. $41 \sim 51$

36）黒正清治, 和田 章, 坂田弘安：ひずみ軟化特性を有す る構造物の非線形解析において収束計算を安定させる一 方法, 日本建築学会大学術講演梗概集, 昭和 61 年 8 月, pp. 681,682

37) Bazant, Z.P., and Belytschko, T. B. : Wave Propagation in Strain-Softening Bar; Exact Solution, Jour. of Engng. Mech., Proc. of ASCE, Vol. 111, No. 3, March 1985, pp. 381 -389

38) Schreyer, H.L., and Chen, Z. : One-Dimensional Softening with Localization, Jour. of Applied Mech., Trans. of the ASME, Vol. 53, Dec. 1986, pp. 791 797

39) Bazant, Z.P., and Panula, L. : Statisticaly Stability Effects in Concrete Failure, Jour. of EM-Div., Proc. of ASCE, Vol.104, No. EM5, Oct. 1978, pp.1195 1212

40）小阪義夫, 谷川恭雄, 畑中重光, 三輪隆治 : RC 梁部材 の塑性ヒンジ部におけるコンクリートの応カーひずみ関 係, 第 8 回コンクリート工学年次講演会講演論文集, 昭 和 58 年, pp. $545 \sim 548$

41) Bazant, Z.P., and Chang, T. : Nonlocal Finite Element Analysis of Strain-Softening Solids, Jour. of Engng. Mech., Proc. of ASCE, Vol.113, No.1, January 1987, pp. 89 105

42）前川宏一, 山崎 淳, 檜貝 勇：材料非線形を考虑した 終局耐力以後の構造解析に関する一考察, $\mathrm{RC}$ 構造の有 限要素解析に関するコロキウム論文集, 昭和 59 年 12 月, pp. 113 118

43）城内哲彦, 戸田哲雄, 森 洋二, 岩崎昭則：鉄筋継手を 有する柱・はり接合部の加力実験, 日本建築学会大会学 術講演梗概集, 昭和 59 年 10 月, pp. 1983, 1984

44）林 静雄, 森本敏幸, 黒正清治：柱はり接合部内に通し 配筋されたはり主筋の付着性状に関する実験と解析, 日 本建築学会構造系論文報告集, 第 357 号, 昭和 60 年 11 月, pp. $101 \sim 111$ 


\section{SYNOPSIS}

UDC : $624.02: 624.04: 693.554$

\section{ELASTIC AND PLASTIC ANALYSIS OF REINFORCED CONCRETE FRAME TAKING INTO CONSIDERATION SHEAR DEFORMATION OF BEAM-COLUMN JOINTS AND BOND-SLIP USING FINITE SEGMENT METHOD}

by HIROYASU SAKATA, Dr. AKIRA WADA, Dr. SHIZUO HAYASHI, and Dr. SEIJI KOKUSHO, Members of A. I. J.

For the purpose of analyzing reinforced concrete frame works, an analytical method is presented here.

Until now, most analytic methods which consider bond-slip or shear deformation of beam-column joints have been 2-dimensional methods, such as the finite element method. Some researchers have made use of beam theory taking into consideration shear deformation of beam-column joints. Others have made use of finite segment method taking into consideration bond-slip. But there have been few analysis of reinforced concrete frame structures taking into consideration the continuity of steel reinforced elements among beam, column and beam-column joint.

The author has reported on the analytic method using finite segment method which considers bond-slip of reinforcing bars.

In this paper, we wish to report on the method that considers the shear deformation of beam-column joints and the continuity of reinforcing bars among beam, column and beam-column joint. The non-linear method discussed in this paper is the incremental method, also referred to as the initial stress method, which has developed on a basis of the stationary principle of incremental potential energy.

We have analyzed a cross-shaped R/C frame construction. Our results compared favorably with experimental data on load-deflection, and strain distribution of reinforcing bars. 